\title{
"I've Got the Pilot": An Interpretation of Flight, a Film by John Gatins, Writer, and Robert Zemeckis, Director
}

\author{
Judith Ferster ${ }^{1}$, Paul Weiser ${ }^{2}$ \\ ${ }^{1}$ English Department North Carolina State University, Raleigh, NC, USA \\ ${ }^{2}$ PRM Financial Services, Inc., Addison, TX, USA \\ Email: jferster@unity.ncsu.edu
}

Received 7 May 2014; revised 15 June 2014; accepted 12 July 2014

Copyright (C) 2014 by authors and Scientific Research Publishing Inc.

This work is licensed under the Creative Commons Attribution International License (CC BY). http://creativecommons.org/licenses/by/4.0/

c) (i) Open Access

\begin{abstract}
Robert Zemeckis's recent film Flight, about a talented but flawed commercial airline pilot (played by Denzel Washington) is discussed on both the realistic and allegorical levels, showing the relationship between the contemporary plot and the fifteenth-century morality play, The Summoning of Everyman. Evidence for and against the different kinds of interpretation is identified and discussed. The film forces the main character to make a series of progressively more difficult and significant ethical decisions about drugs, alcohol, friends (true and false), lovers, and personal atonement that challenge him. The audience must make an interpretive decision between the possible levels of meaning.
\end{abstract}

\section{Keywords}

John Gatins (Writer), Denzel Washington, Everyman, Morality Play, Good Works, Confession, Cinema

\section{Introduction}

More powerfully and single-mindedly than many recent movies, "Flight" forces its protagonist to make a climactic moral choice. Screenwriter John Gatins’s story propels Whip Whitaker, played by Denzel Washington, into a stark decision. Along the way it raises questions on a realistic level about an airplane crash and how most of its passengers survived, but ultimately Whip, a successful commercial pilot who supplements copious amounts of alcohol with cocaine, must decide if he will take responsibility for the way he lives and works. This is his chance to be a grown-up, but events conspire to provide him with ways to avoid it. Will he face his de- 
mons and the consequences of his actions or continue to flee?

That question and the details of the crash seized the two of us when we watched "Flight" during its first run in 2012. We believe that with our varied backgrounds, we can comment on the questions the film raises on both the literal and the ethical levels: One of us is a retired literature professor and the other an Air Force veteran, each being interested in the other's fields. We hope that our collaboration will allow us to shed some light on both the literal questions this film raises and the ethical quandaries that make it compelling for viewers and a challenging vehicle for its star.

\section{Naturalistic Interpretation}

Whip Whitaker is engaging partly because of his contradictions: he's a gifted pilot able to maneuver daringly around thunderstorms, but his blood alcohol level is routinely above where it should be. The tension is heightened when the flight suffers a potentially fatal mechanical difficulty-the stabilizer jackscrew is stripped, forcing the plane into an irreversible dive. It is on its way to a catastrophic crash when Whip (almost instinctively, he says later) turns the plane upside down. He flies inverted until it's time to land. All the passengers except six (some were not wearing their seatbelts) survive the crash. Just before the plane lands in a grassy open space, a wing shears off the steeple of a church. Worshippers in billowing white robes pour out to help passengers and crew to safety. One pulls the injured Whip out of the wreckage calling to the others in the congregation, "I've got the pilot”. But can the forces of good set Whip on the path to righteousness? That question takes the rest of the film to answer. In this essay, we plan to take on the literal questions in the plot, including whether commercial jetliners can fly upside down and whether cocaine can enhance the performance of people intoxicated with alcohol, and follow the ethical intricacies of Whip's journey to see if his talent for growing into adulthood can match his prodigious talent for flying.

After the crash, the airline puts ten pilots in flight simulators under the conditions of Whip's emergency. None successfully lands the plane. The media prepare to treat Whip as a hero, but his blood alcohol level, higher than airline and Federal Aviation Association standards, could land him in prison for manslaughter. The incriminating test results are among the obstacles removed from Whip's path. Hugh Lang, a clever lawyer from the pilots' union (played by Don Cheadle) suppresses the report and indulgent co-workers, even the religious co-pilot Ken Evans (Brian Geraghty) lie for him. By the third-last scene, which took place at a National Transportation Safety Board hearing, to walk away scot-free free Whip need only blame flight attendant Nadine Marquez (Katerina Velazquez) for two empty bottles of vodka found in the plane's trash after the accident. She is known to have had a drinking problem and is conveniently dead, a perfect scapegoat unable to defend herself. She was Whip's lover and died because she unbuckled her seatbelt to save a boy, but she was beyond injury and all Whip had to do to exonerate himself was to let suspicion of a relapse fall on her. The plot, which could be called "The Temptation of Whip”, forced him to choose.

The audience of the film has further choices to make. On the level of form and theme, viewers might wonder whether the film, with its provocatively named protagonist (smart as a whip? Whipped into shape?) and its white-robed religious rescuers, is an allegory. On the literal level, they might wonder whether Whip's almost miraculous method of avoiding an uncontrolled descent (especially given his drug cocktail) is realistic. What he does-instinctively, and he testifies at the hearing - is to roll the plane upside down. According to pilot Patrick Smith, host of the Daily Beast webpage “Ask The Pilot: All Things Air Travel”, the cinematic mishap resembles the mechanical failure of Alaska Airlines 261 in January of 2000, when the jammed stabilizer jackscrew (in the movie it was stripped) forced the plane into the dive (http://www.thedailybeast.com/articles/2012/11/18/real-pilots-laugh-at-flight.html [(Downloaded 11/3/13 23:53 EST]). But can jet liners fly inverted? Smith is not sure, but a number of Air Force pilots say “yes”. Flying upside down is natural to stunt pilots and a necessity when mechanical failure forces an uncommanded nose-down attitude. The angle of attack must be adjusted, but many planes fly as well upside down as they do right side up.

Another question on the literal level might be whether mixing alcohol and cocaine (along with a few whiffs of pure oxygen) would allow the protagonist to drive anything, let alone a commercial jetliner. Can cocaine revive a drunk the way that spinach energizes Popeye? A study by Higgins et al., 1992 on the effects of the two drugs, the first a depressant and the second a stimulant, says that the combination disrupts learning and behavior less than alcohol alone. This analysis makes it plausible that Whip's mix of chemicals compensates for his inebriation. He is an alcoholic who snorts cocaine to make him alert enough to function in his daily life and job. Cocaine might indeed balance the chemistry of a hangover, especially if the pilot has what New Journalist Tom 
Wolfe (Wolfe, 1979) calls "the right stuff”.

According to Wolfe's account of the flight during which test pilot Chuck Yeager broke the sound barrier, Yeager was not hung over when he tested the Bell X-1, but he had been so drunk when he went riding two nights before that he fell off his horse and broke several ribs. On the day of the test, he was so under the influence of pain that he could not close the plane's hatch in the usual way. He needed a specially engineered broom handle. Wolfe's book, The Right Stuff, and the film based on it, helped to create the cultural icon of the cool-under-pressure pilot. This figure helped Americans accept and lionize Captain Chesley Sullingberger, who in 2009, when his plane's engines were damaged by collision with a flock of geese, landed safely—with no casualties — on the Hudson River. It also helps us accept that Whip's quick thinking could avert a catastrophic nose-down crash and allow the survivable (for passengers in seatbelts) landing in a grassy field.

The portrayal of these events in Whip's life as extraordinary but possible keeps the film on its naturalistic course. But naturalism is not the only key to this film.

\section{Beyond Naturalism}

According to Patrick Smith in the Daily Beast article we cited above, the least realistic part of the film (what makes real pilots laugh at it) is the way that the pilot's union and its lawyer function as enablers for Whip's addiction. Drug and alcohol tests are unannounced and common. Air carriers and unions like the Air Line Pilots Association have been very successful with proactive counseling programs that encourage pilots to seek treatment. In other words, it wouldn't have taken a crash for the FAA, the airlines, and the unions to get wise to Whip's chemical indiscretions.

The angelic Baptist delivering Whip from the wreckage and the media's counting the "souls" on board are not the only clues to the moral theme in the plot. Whip’s jovial fast-talking drug pusher, Harling Mays (John Goodman), who can deliver the requisite drugs wherever Whip goes, is not solely realistic, either. His introductory theme music is The Rolling Stones' "Sympathy for the Devil", which begins, "Please allow me to introduce myself”, and recounts his role in some of the violent moments in history and his success in stealing men's souls and faith. His repeated refrain is "Pleased to meet you/Hope you guess my name". The song addresses the audience and makes the film into something of a moral allegory.

In fact, the film's plot bears a surprising resemblance to the late fifteenth-century morality play, The Summoning of Everyman (Anonymous, 1993). The main character, Everyman, learns that he is dying and turns to personified attributes-for instance, Beauty, Discretion, Wealth, Strength, the Five Wits, Friendship, Kindred, Goods, Knowledge, and Good Deeds—asking that they accompany him to the reckoning that will determine where he will spend eternity. All refuse. Finally Knowledge (standing for self-awareness) prompts him to make a confession (a positive start), allowing Good Deeds to stay with him on his journey.

Whip is not preparing for imminent death, but there is a struggle (for his soul?) between his drugs and a sober and more responsible life. He tries sobriety with a new lover (Nicole Maggen), an addict who asks him to help her by staying sober and who takes him to an Alcoholics Anonymous meeting, but he leaves early, binges, and loses her.

The lawyer for the pilots' union and Whip’s pilot friend Charlie Anderson require that he get sober for the NTSB hearing, the last thing that makes him vulnerable to punishment. They try to enforce sobriety by locking him in a hotel room with a mini-bar purged of alcohol and a guard outside the door to prevent the entrance of all tempters and temptations. But by chance the door to the adjoining room opens and by morning the encounter with the unpurged mini-bar leaves him in a drunken stupor. The ministrations of his profane Falstaffian drug connection Harling Mays get him on his feet, ready to be a credible witness. But when the examiner asks him whether he thinks that the flight attendant with the past history of alcohol drank the vodka from the now-empty bottles, he hesitates several times, mutters, "God help me” under his breath, and saves Marquez's reputation by confessing that he drank the vodka himself. Somehow, although his addiction has accustomed him to lying, he cannot save himself by destroying Marquez's reputation. In their night together before the flight, he played with the idea that she might become his second wife, and she had sacrificed herself to save a child. Perhaps because of love, honor, or shame, he is finally able to escape the maze of addiction and take the straight path.

The penultimate scene of the movie shows Whip introducing himself as an alcoholic to an AA meeting. As he speaks, the camera zooms back to reveal that he is in prison. In the terms of the morality play, he now has the (self)-knowledge required for confession. No longer in flight from himself or the discipline of his profession, 
grounded in his new self-understanding, Whip can now form a new bond with his estranged son, who asks to interview him for a school assignment. Knowledge leads to confession, thence to a good deed-the lasting wealth of the film's modern Everyman.

\section{References}

Anonymous (1993). Everyman. Last Checked 8 April 2014.

http://quod.lib.umich.edu/cgi/t/text/text-idx?c=cme;cc=cme;view=toc;idno=Everyman

Higgins, S. T., Rush, C. R., Hughes, J. R., Bickel, W. K., Lynn, M., \& Capeless, M. A. (1992). Effects of Cocaine and Alcohol, Alone and in Combination, on Human Learning and Performance. Journal of the Experimental Analysis of Behavior, 58, 87-105.

Wolfe, T. (1979). The Right Stuff. Farrar, Straus, and Giroux, New York. 
Scientific Research Publishing (SCIRP) is one of the largest Open Access journal publishers. It is currently publishing more than 200 open access, online, peer-reviewed journals covering a wide range of academic disciplines. SCIRP serves the worldwide academic communities and contributes to the progress and application of science with its publication.

Other selected journals from SCIRP are listed as below. Submit your manuscript to us via either submit@scirp.org or Online Submission Portal.
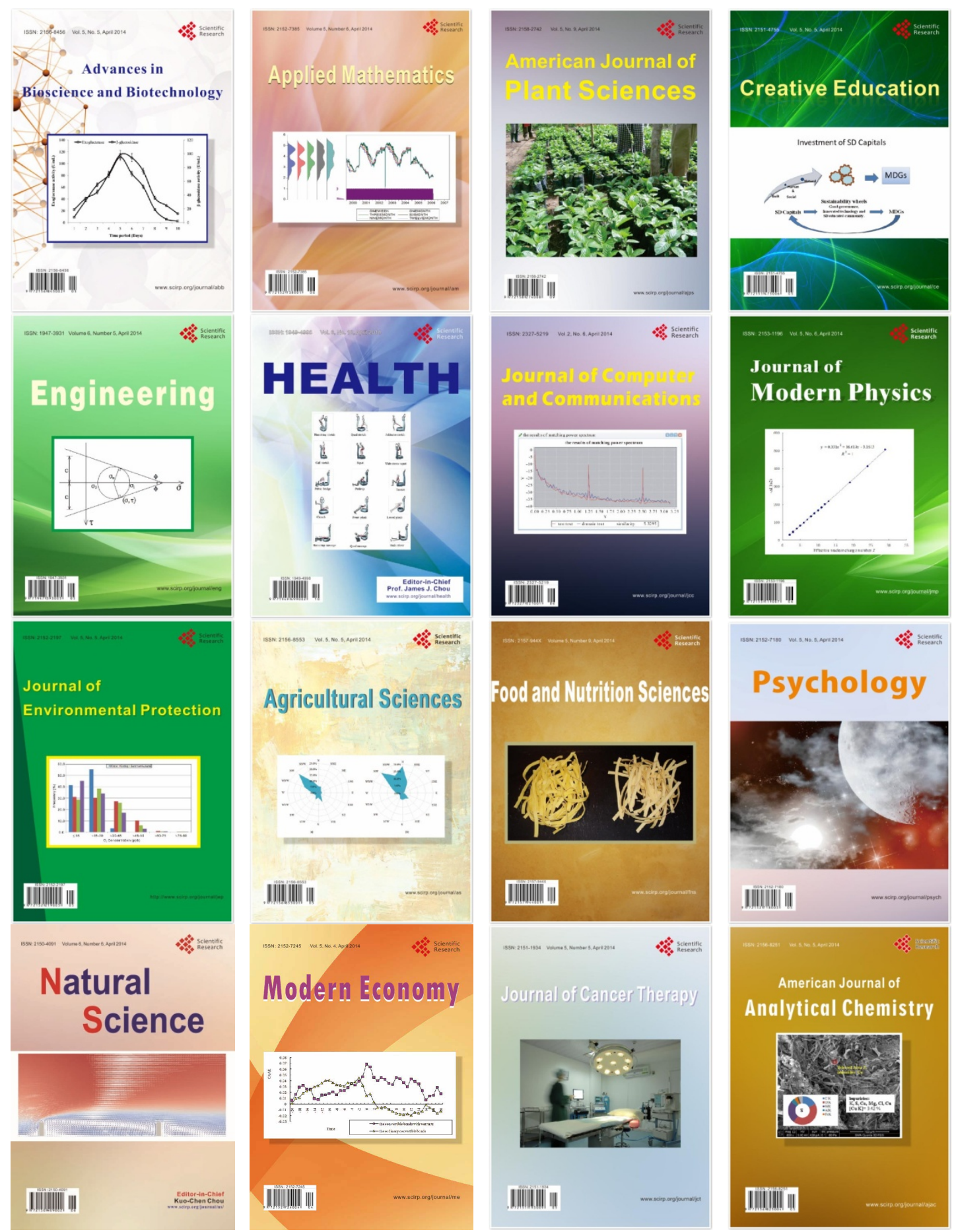